\title{
Target Costing Evolution: A Review of the Literature from IFAC's (1998) Perspective Model
}

\author{
Hussein H. Sharaf-Addin ${ }^{1,2}$, Normah $\operatorname{Omar}^{2} \&$ Suzana Sulaiman ${ }^{2}$ \\ ${ }^{1}$ Faculty of Administrative Sciences, Thamar University, Yemen \\ ${ }^{2}$ Faculty of Accountancy, Universiti Teknologi MARA (UiTM), Malaysia \\ Correspondence: Hussein H. Sharaf-Addin, Faculty of Administrative Sciences, Thamar University, Yemen. \\ E-mail: sharafidr@yahoo.com
}

Received: March 17, 2013 Accepted: April 19, 2013 Online Published: April 29, 2014

doi:10.5539/ass.v10n9p82 URL: http://dx.doi.org/10.5539/ass.v10n9p82

\begin{abstract}
During the last two decades, with increasing competition in highly changing business environment, literature has cautioned against the efficiency and capability of traditional management accounting techniques in providing sufficient information needed for decision making. In coping with continuing changes in business environment and increasing pressure of competition, cost and management accounting techniques have been changed and new techniques have been developed, especially in the last two decades. This is to enable organizations to stay competitive by producing better quality products at lower costs. As Target Costing (TC) has been innovatively adopted to achieve this objective by Japanese companies in the 1960s, this paper attempts to show the historical development of TC. Premised on the review of forty (42) refereed journal articles published in various accounting journals during the periods of 1984 to 2013, this paper shows how, over times, the TC practices have undergone a three-phase evolution from cost reduction and control to cost and profit management and to quality and functionality improvement. Specifically, the paper examines the evolutionary facet of TC by using the 1998 IFAC-based management accounting evolution framework.
\end{abstract}

Keywords: cost accounting, cost control system, management accounting, target costing evolution

\section{Introduction}

Increased pressure of customers' demand coupled with increased competition among manufacturers in the last two decades formed the basis of cost and management accounting development. Numerous advanced cost and management accounting techniques, such as Target Costing (TC), have been promoted by many organizations worldwide in response to the competitive challenges and in pursuing their overall strategic goals. However, as Kaplan's (1984) review of The Evolution of Management Accounting and Johnson and Kaplan's (1987) book of Relevance Lost criticized the management accounting practices during the $1980 \mathrm{~s}$, several management accounting innovations have been developed across a range of industries and implemented internationally (Abdel-Kader \& Luther, 2006). In addition, Johnson and Kaplan (1987) argued that management accounting had not changed since the early twentieth century and had lost its relevance in providing information for decision making. But in fact, there is growing evidence that the management accounting techniques have been developed and promoted across a wide range of industries. In particular, TC was initially developed by Japanese Toyota Corporation in the 1960s. The concept, which was known as the Toyota Production System (TPS), was aggressively promoted by Toyota and was later adopted by other non-Japanese companies. Despite the fact that detailed information about TPS was made available by Toyota Corporation, not all companies were able to emulate the systems. Effectively, only those manufacturing companies with the right organizational capabilities (OCs) were able to successfully emulate TPS. In particular, the OCs related to product development strategy and customers' expectations analysis have been recognized as success factors for management accounting practices including TC (Hamood, Omar \& Sulaiman, 2011).

However, following the oil crisis in 1973, more innovations were introduced to the production system of manufacturing companies. That period was later recognized as an era when management accounting underwent the most advanced stage of innovation. Essentially, cost and management accounting techniques were used to ensure product competitiveness in terms of design, development, and cost. Hence, it is very interesting to explore, through previous studies review, how the focus of TC has been developed globally by many organizations as a 
response to the competitive challenges. Moreover, the scope of the TC functions and the wide range of TC implementation across different countries have evolved globally and consistently with management accounting development.

However, literature upholds the wide adoption of advanced cost and management accounting techniques by providing evidences of transforming traditional techniques into newly developed techniques. For example, cost-plus pricing method has been criticized by many researchers and practitioners, and changed with market-oriented pricing method. Meanwhile, there is a consensus among researchers and practitioners that the cost-plus traditional method has failed in meeting the competitive pressures and customers' expectations in the business environment. Despite the early establishment of TC in the 1960s, it continuously enables organizations to deal with the external changes in the marketplace. Based on Helms, Ettkin, Baxter, and Gordon (2005), TC works "backward" from traditional cost-plus methods and starts with a targeted selling price of a product. This price is constrained in the TC framework by the marketplace, and determined by the entire industry value chain analysis and across all organizational functions including top management support (Yalcin, 2011). Similarly, Cooper and Slagmulder (1997) describe TC as a feed-forward cost management technique rather than the traditional feed-back techniques used to manage product cost during the design and development stage. Therefore, TC is mainly initiated as a cost management technique to drastically manage product features; cost, quality, and functionality; at the earlier stages of products life cycles based on the customers' expectation and competitive market.

\section{Research Issues and Objectives}

The literature has recently addressed TC approach as an open system integrating various cost and management accounting techniques consistently with value creation and integration process as seen by IFAC (1998). For instance, integrating TC with Kaizen Costing (Monden \& Hamadah, 1991), TC with Activity-based Costing (ABC) (Cokins, 2002), TC with Balanced Scorecard (BSC) (Souissi \& Ito, 2004), and incorporating TC with Quality Function Deployment (QFD) and Value Engineering (VE) in Jariri and Zegordi's (2008) mathematical model. In view of this development, the current paper is examining the evolution of TC as a strategic concept as one of the most prominent techniques described by various researchers as a price-based approach for the products, and derived from market price and profit planned. The paper attempts to consider the TC evolution based on IFAC's (1998) framework of management accounting evolution.

In addressing the research issues and objectives, the remainder of the paper is organized as follows. Section three (3) provides literature review where the introduction of management accounting system, the evolution framework and the four stages of management accounting evolution described by IFAC (1998) are considered. The concern will be particularly focused on the development of cost and management accounting techniques through which TC is being developed. The historical context of cost control system, in which TC is supposed to be a major tool for cost reduction and control, is also reviewed in this section where much emphasis is given to the cost control techniques to provide an overview of each technique for the purpose of addressing the evolution of TC among the stages of cost control system development. Section four (4) provides the methodology used in the study. Section five (5) presents the findings of the study. The findings include the evolutionary diagram of cost control system by which the evolutionary diagram of TC is developed to illustrate how TC was initiated, and to foster its development through the last two decades until its current utilization. This briefly reviews the changes of TC's focus, which is consistent with management accounting evolution stages over the last century since was discussed in the literature. Finally, the paper is concluded with a brief discussion on the entire purposes of the study in Section six (6) and concluding remarks on the current development of TC in Section seven (7).

\section{Literature Review}

\subsection{Introduction of Management Accounting System}

As management accounting innovation has become a major element of the successful performance in today's competitive environment, the setting of strategies as a direction toward that innovation has been a crucial factor. The changes in management accounting system in coping with increased competition have been criticized by accounting literature. Johnson and Kaplan (1987) argued that management accounting had not changed since the early twentieth century, and lost its relevance for the purpose of providing information for decision making process. In response to this criticism, newly developed management accounting techniques have been developed and adopted by many organizations around the world. Based on the "Asian management accounting practices" model suggested by Nishimura (2002), the management accounting is classified into four development stages: "drifting" management accounting, "traditional" management accounting, "mathematical" management 
accounting, and "integrated" management accounting. Through these stages, the management accounting is generally evolved from focusing on financial accounts for management control in the first stage toward integration of accounting management and organizational management in the fourth stage. Moreover, the appearance of e-commerce and growth of advanced technology have increased the competitive challenges and therefore shifted the focus of management accountants toward value-added activities and efficient use of resources. Therefore, numerous recent management accounting techniques have been adopted such as Total Quality Management (TQM), Just-in-Time (JIT), Balanced Scorecard (BSC), Activity-based-Costing (ABC), and Target Costing (TC). This is to prop up the modern technologies and complex management processes.

In addition, the role of environment in which the companies operate and management accounting system is practiced affects the organizational structure and the implementation of new management accounting techniques. Many studies argue that the modern management accounting techniques recently adopted by many organizations affect the management accounting functions (planning, controlling, communication, and decision making) and then shift its focus from a simple role of cost determination and financial control to a sophisticated role of value creation (Abdel-Kader \& Luther, 2008). This can be achieved through the use of technologies which check up the drivers of customers' value, shareholders' value, and organizational innovation (IFAC, 1998). Hiromoto (1991) explores the role of Japanese management accountants in linking the corporate strategies with their management accounting systems. This is obviously noted in their attempt to adopt non-financial measures rather than financial measures to realize low cost, high quality, and timely delivery of products. Hiromoto, therefore, indicated that the non-financial measures, cost allocation system and market-driven management system are innovations centered on a single theme: "the design of measurement and control systems for continuous innovation". According to his suggestion, traditional management accounting should play an "information for decision-making" role and help to obtain the optimal activities with regard to the current conditions. In essence, the serious attention of many organizations is to integrate various techniques including the traditional techniques for the purpose of achieving strategic goals. For example, TC technique is more likely supported by information typically driven from a cost of quality reporting system (Bright, Davies, Downes \& Sweeting, 1992).

\subsection{Management Accounting Evolution Framework}

Based on the literature reviewed, there is a consensus among academicians and practitioners toward the need of developing a conceptual framework to describe the best practice of management accounting techniques. This can clearly be seen in the framework developed by IFAC (1998) explaining the four stages of management accounting evolution. The framework developed is to support the new management accounting techniques such as TQM, JIT, BSC, and TC so as to capture the technological development in business environment and meet the global competitive challenges. Interestingly, the use of IFAC's (1998) framework in the current study is to describe the TC function as TC is considered to be one of the management accounting techniques. Moreover, the similarity of TC role with certain aspects of management accounting roles described in the framework can be found in the shift of TC objective of cost reduction toward product value creation in terms of quality and functionality. Hence, the framework is supposed to be a supportive guide of TC approach in highly competitive environment. However, IFAC (1998; para 37) provides the conceptual framework to describe the role of management accounting developed in its four stages of evolution. Figure 1 shows the conceptual framework of management accounting developed through a set of concepts categorized in terms of a distinctive function of management accounting within the management process, the way in which the utility of management accounting outcomes can be tested, the criteria which can be used to evaluate the management accounting processes and technologies, and the capabilities necessarily associated with the effectiveness of management accounting function as an overall. 


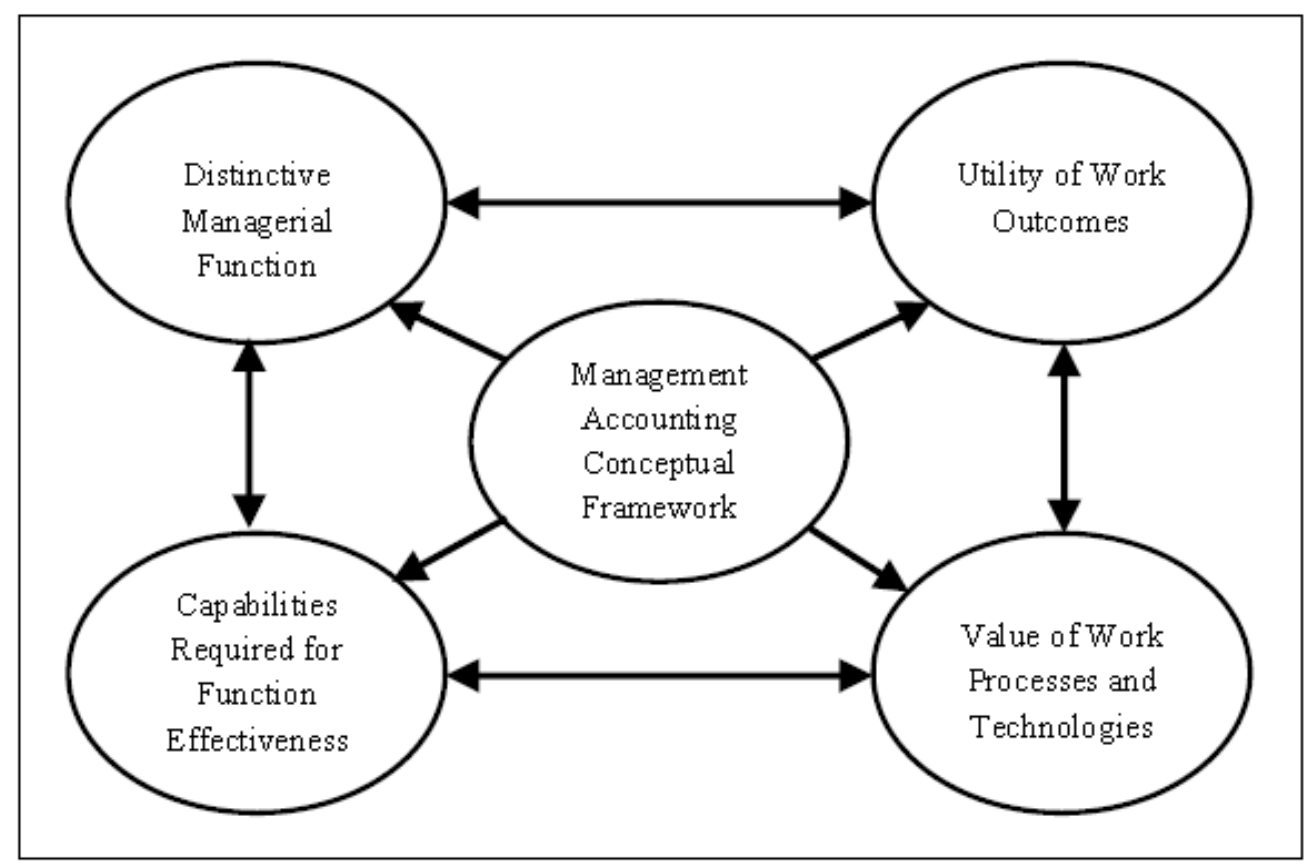

Figure 1. The conceptual framework of management accounting

Source: IFAC (1998)

By using the framework illustrated above, the development of management accounting practices to ensure value creation through the effective use of resources can be derived. In addition, each concept within the framework is linked with others to describe the distinctive focus of management accounting on the effective use of resources to generate value (known as management accounting function) in both financial and non-financial forms. Similarly, the four concepts in the framework describe the best practice of TC technique where TC depends aggressively on organizational capabilities included within these four concepts.

\subsection{The Stages of Management Accounting Evolution}

Figure 2 shows the four stages derived from IFAC (1998) statement on management accounting concepts. However, in the first stage (prior to 1950), the primary focus of management accounting was cost determination and financial control. This is predominantly concerned with the internal processes, budgeting and cost accounting practices.

In addition, due to the urgent need for information in decision making process, the role of management accounting is shifted to the provision of information needed for planning and control purposes. This is shown in the second stage of management accounting evolution model (1950s to 1960s). According to Abdel-Kader and Luther (2008), the management activities during this period involved the staff support of line management through the use of technologies and management controls oriented towards manufacturing and internal administration rather than strategic and environmental considerations. Use of technologies refers to the models of thought and practice used in the processes involved in the organizational activities and is associated with each part of the management process (IFAC, 1998, para 27), where management accounting is an integral part of the management process (IFAC, 1998, para 29). Therefore, it is more interesting to note that management accounting, as a part of management process, focuses on the effective ways to manage resources in order to achieve organizations' objectives set in the strategy. 


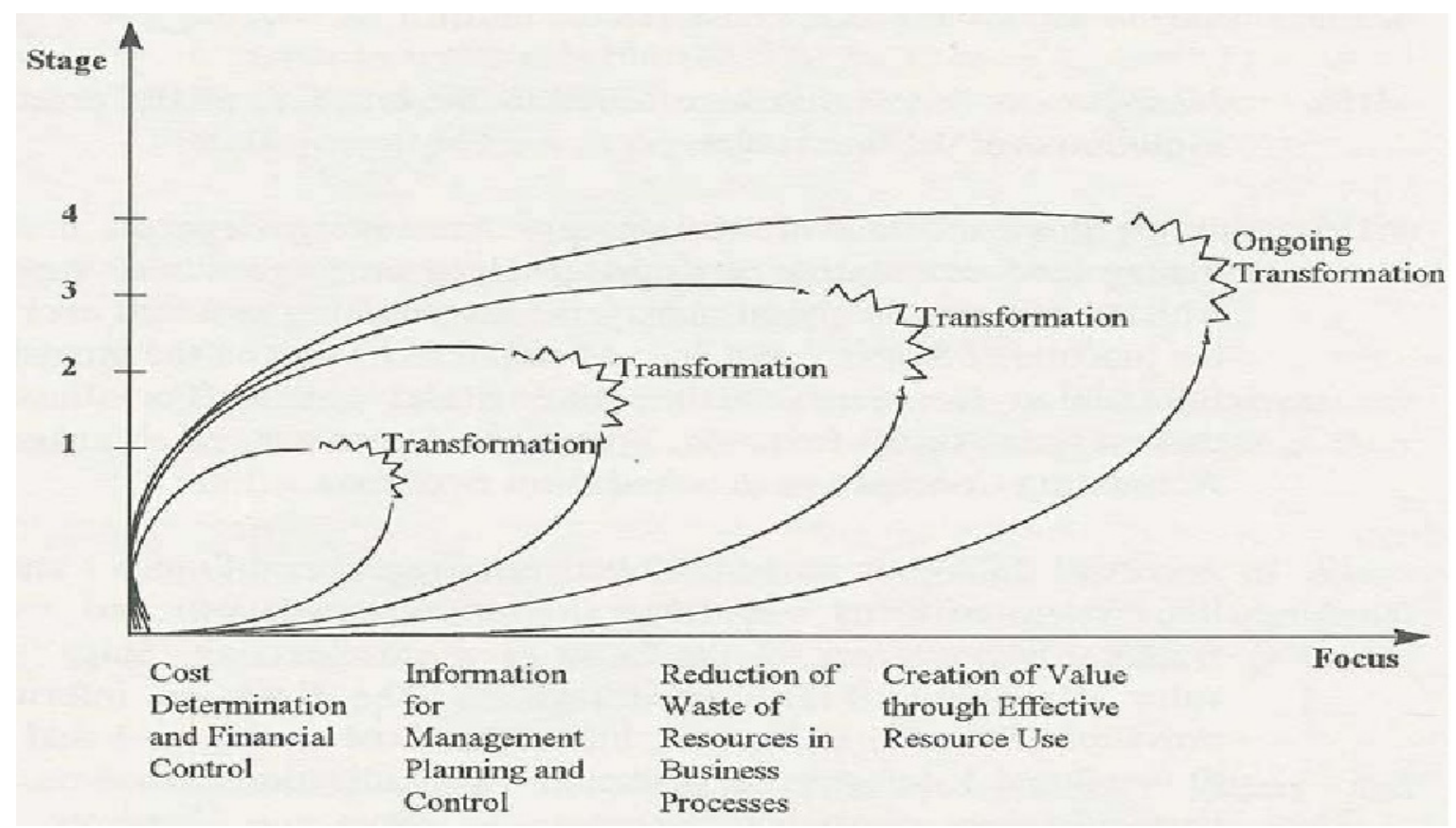

Figure 2. The evolution of management accounting

Source: IFAC (1998)

In IFAC's third stage of management accounting evolution framework, the management role is shifted towards reduction of waste in resources used in organizations' processes (IFAC, 1998, para 7). This is partly due to the world recession in the 1970s following the oil price shock and the increase of competition in the early of 1980s (Abdel-Kader \& Luther, 2008). Therefore, the need of information systems adopted by management accountants is urgently essential to ensure the availability of appropriate information needed to support managers and other users at all organizations' levels. Ashton et al. (1995), as cited by Abdel-Kader and Luther (2008), report that the impact of uncertainty, advances in manufacturing, and information-processing technologies, and overall challenges of global competition faced by world-wide industry in the 1990s led to the appearance of e-commerce. This, therefore, shifts the role of management accounting in its fourth stage of evolution towards value creation through the effective use of resources and technologies which examine the value drivers of customers, shareholders, and ultimately organizational innovation.

Through the four stages of management accounting evolution, it can be seen that all stages are successively linked with each other; one stage encompasses the concepts of the previous one. However, the major difference between stage 2, stage 3 and stage 4 is that the focus shifted from information provision towards resources management, waste reduction in stage 3 and value creation on stage 4 (IFAC, 1998, para 17). Hence, newly developed management accounting techniques such as JIT, BSC, and TC are to achieve the fundamental role of management accounting in terms of value creation articulated in the stage 4. Accordingly, TC focus is to integrate all the last three stages (stage 2, stage 3, and stage 4) towards value creation objective through determining of products target costs, providing information for planning and designing purposes, and controlling product costs through reduction of waste in resources used in production process. The detailed discussion on TC role developed as an integral part of cost and management accounting system consistent with management accounting evolution stages is presented in the findings section.

\subsection{Cost Control System}

During the last two decades, the conventional cost control system has been criticized by academic literature due to its inability to provide efficient and latest information for decision makers and other potential users. In addition, it is necessary to note that, in coping with increasing competitive pressure in manufacturing industries, cost control system should be given an extensive attention to be a supportive system for management accounting innovations with the requirements of products' cost control. According to Filomena, Jose, Neto, and Duffey, (2009) the practical application of cost control during New Product Development (NPD) requires detailed and available information of product constituent elements. Despite TC has been described as an excellent tool 
initiated to control product costs, its operationalization with other cost control tools and functional teams involved require careful decomposition of products elements such as features, characteristics, parts and functions (Filomena et al., 2009). However, to understand when the cost control system has been initiated and its historical context has been developed. Albright and Lam (2006) mentioned that the advent of modern manufacturing, known as the second industrial revolution, began in the early 1900s. They added that the two important developments, that emerged from Japanese companies during the 1940s, were JIT and Kanban (a scheduling system of production based on customers' demand) to control cost with an emphasis on quality. These techniques linked with TQM were the central approaches of Toyota Production System (TPS) toward production efficiency. The techniques then are followed by "Lean Production" system in 1950 to control waste by eliminating all activities that consume resources without value creation (Womack \& Jones 1996; as cited by Albright \& Lam, 2006).

According to Kaplan (1984), the challenges in the competitive environment have led to the reexamination of traditional cost accounting and management control system. Numerous studies comment that the traditional cost control system involves inadequate mechanisms and techniques to provide a competitive management accounting information needed for decision making process, such as Standard Costing and Variance Analysis, Budgeting and Cost-Volume-Profit Analysis (e.g. Monden \& Lee, 1993; Feil et al., 2004; Modarress, Ansari \& Lockwood, 2005; Albright \& Lam, 2006). These techniques have not become the efficient tools to be used in a severely changing business environment. However, the usefulness of Standard Costing, originally adopted as a primary cost control technique in US firms (Monden \& Lee, 1993), has been criticized by many practitioners and academicians. For example, Berliner et al. (1988), as cited by Modarress et al. (2005), argue that Standard Cost accounting utilizes performance measures which are in conflict with manufacturing goals, and cannot adequately assess the importance of non-financial measures such as quality and flexibility. As Standard Costing, in particular, has been a primary tool in cost control system which aims to meet the cost standards, Kaizen Costing is operating outside Standard Costing which focuses on the actual cost reduction below the standards costs (Monden \& Lee, 1993). Monden and Hamadah (1991) also reveal that Kaizen Costing in Japanese automobile industries is not implemented according to Standard Costing system. Hence, the initial technique used in cost control system is Standard Costing but in the aim of meeting the cost standards in order to evaluate the company's performance through the variance analysis process between actual and standard costs. However, meeting the cost standards has been extended to include cost reduction goal throughout the production stage (Kaizen Costing) and the design and development stage of product life cycles (TC).

\section{Methodology}

The main objective of current study is to examine the TC evolution in terms of practices in different periods based on management accounting evolution derived from IFAC (1998) as TC is one of management accounting techniques. This is based on the review of the literature carried out from 1984-2011 (27 years covering three decades) in the field of management accounting practices, TC concepts and its development and practices in different countries. The study critically reviews a total of thirty forty (40) articles written and published in the English language in different refereed international journals globally (see Table 1). 
Table 1. Articles reviewed according to the year of publication

\begin{tabular}{|c|c|c|c|c|c|}
\hline No. & Articles & $\begin{array}{c}\text { Journals and Year of } \\
\text { Publication }\end{array}$ & No. & Articles & $\begin{array}{c}\text { Journals and Year of } \\
\text { Publication }\end{array}$ \\
\hline 1. & $\begin{array}{l}\text { The evolution of management } \\
\text { accounting }\end{array}$ & $\begin{array}{l}\text { The Accounting Review } \\
\text { (1984) }\end{array}$ & 13. & $\begin{array}{l}\text { Adoption and benefits of } \\
\text { management accounting } \\
\text { practices: an Australian study }\end{array}$ & $\begin{array}{l}\text { Management Accounting } \\
\text { Research (1998) }\end{array}$ \\
\hline 2. & $\begin{array}{l}\text { Restoring the Relevance of } \\
\text { Management Accounting }\end{array}$ & $\begin{array}{l}\text { Journal of Management } \\
\text { Accounting } \quad \text { Research } \\
\text { (1991) }\end{array}$ & 14. & $\begin{array}{l}\text { Advanced } \text { Management } \\
\text { Accounting Techniques in } \\
\text { Manufacturing: Utilization, } \\
\text { Benefits, and Barriers to } \\
\text { Implementation. }\end{array}$ & $\begin{array}{l}\text { Accounting Forum } \\
(2000)\end{array}$ \\
\hline 3. & $\begin{array}{l}\text { Target costing and kaizen } \\
\text { costing in Japanese } \\
\text { automobile companies }\end{array}$ & $\begin{array}{l}\text { Journal of Management } \\
\text { Accounting } \quad \text { Research } \\
\text { (1991) }\end{array}$ & 15. & $\begin{array}{l}\text { The international diffusion of } \\
\text { new management accounting } \\
\text { practices: the case of India }\end{array}$ & $\begin{array}{l}\text { Journal of International } \\
\text { Accounting, Auditing and } \\
\text { Taxation (2001) }\end{array}$ \\
\hline 4. & $\begin{array}{l}\text { The development of costing } \\
\text { techniques and practices: A } \\
\text { UK study }\end{array}$ & $\begin{array}{l}\text { Management Accounting } \\
\text { Research (1992) }\end{array}$ & 16. & $\begin{array}{l}\text { Integrations of Target Costing } \\
\text { and } \mathrm{ABC}\end{array}$ & $\begin{array}{l}\text { Journal of Cost } \\
\text { Management (2002) }\end{array}$ \\
\hline 5. & $\begin{array}{l}\text { Target costing support } \\
\text { systems: Lessons from } \\
\text { leading Japanese companies }\end{array}$ & $\begin{array}{l}\text { Management Accounting } \\
\text { Research (1993) }\end{array}$ & 17. & $\begin{array}{l}\text { Asia Economic Growth and } \\
\text { Management Accounting, }\end{array}$ & $\begin{array}{l}\text { Malaysian Accounting } \\
\text { Review (2002) }\end{array}$ \\
\hline 6. & $\begin{array}{l}\text { How a Japanese auto maker } \\
\text { reduces costs }\end{array}$ & $\begin{array}{l}\text { Management Accounting } \\
\text { (1993) }\end{array}$ & 18. & $\begin{array}{l}\text { A survey of the adoption and use } \\
\text { of target costing in Dutch firms }\end{array}$ & $\begin{array}{l}\text { Int. J. Production } \\
\text { Economics (2003) }\end{array}$ \\
\hline 7. & $\begin{array}{l}\text { Management accounting } \\
\text { (1984-1994): development of } \\
\text { new practice and theory }\end{array}$ & $\begin{array}{l}\text { Management Accounting } \\
\text { Research (1994) }\end{array}$ & 19. & $\begin{array}{l}\text { An Empirical Investigation of the } \\
\text { Evolution of Management } \\
\text { Accounting Practices }\end{array}$ & $\begin{array}{l}\text { University of Essex, } \\
\text { Working Paper Series } \\
(2004)\end{array}$ \\
\hline 8. & $\begin{array}{l}\text { Target cost management in } \\
\text { Japanese companies: current } \\
\text { state of the art }\end{array}$ & $\begin{array}{l}\text { Management Accounting } \\
\text { Research (1994) }\end{array}$ & 20. & $\begin{array}{l}\text { Integrating target costing and the } \\
\text { balanced scorecard }\end{array}$ & $\begin{array}{l}\text { The Journal of Corporate } \\
\text { Accounting \& Finance } \\
\text { (2004) }\end{array}$ \\
\hline 9. & $\begin{array}{l}\text { Interactive control in target } \\
\text { cost management }\end{array}$ & $\begin{array}{l}\text { Management Accounting } \\
\text { Research (1995) }\end{array}$ & 21. & $\begin{array}{l}\text { Japanese Target Costing: A } \\
\text { Historical Perspective }\end{array}$ & $\begin{array}{l}\text { International Journal of } \\
\text { Strategic Cost } \\
\text { Management (2004) }\end{array}$ \\
\hline 10. & $\begin{array}{l}\text { Cost Reduction Systems: } \\
\text { Target Costing and Kaizen } \\
\text { Costing }\end{array}$ & Productivity Press (1995) & 22. & $\begin{array}{l}\text { Kaizen costing for lean } \\
\text { manufacturing: a case study }\end{array}$ & $\begin{array}{l}\text { International Journal of } \\
\text { Production Research } \\
(2005)\end{array}$ \\
\hline 11. & $\begin{array}{l}\text { A Powerful Tool for } \\
\text { Diagnosis and Strategy }\end{array}$ & $\begin{array}{l}\text { Journal of Management } \\
\text { Consulting (1997) }\end{array}$ & 23. & $\begin{array}{l}\text { Managerial Implications of } \\
\text { Target Costing }\end{array}$ & CR (2005) \\
\hline 12 & $\begin{array}{l}\text { Target Costing: The Next } \\
\text { Frontier in Strategic Cost } \\
\text { Management }\end{array}$ & $\begin{array}{l}\text { Iwrin Professional } \\
\text { Publishing (1997) }\end{array}$ & 24. & $\begin{array}{l}\text { The evolution of management } \\
\text { accounting innovations and the } \\
\text { level of satisfaction with } \\
\text { traditional accounting techniques. }\end{array}$ & $\begin{array}{l}\text { AFAANZ } \\
(2005)\end{array}$ \\
\hline
\end{tabular}


Table 1. Articles reviewed according to the year of publication (Cont'd)

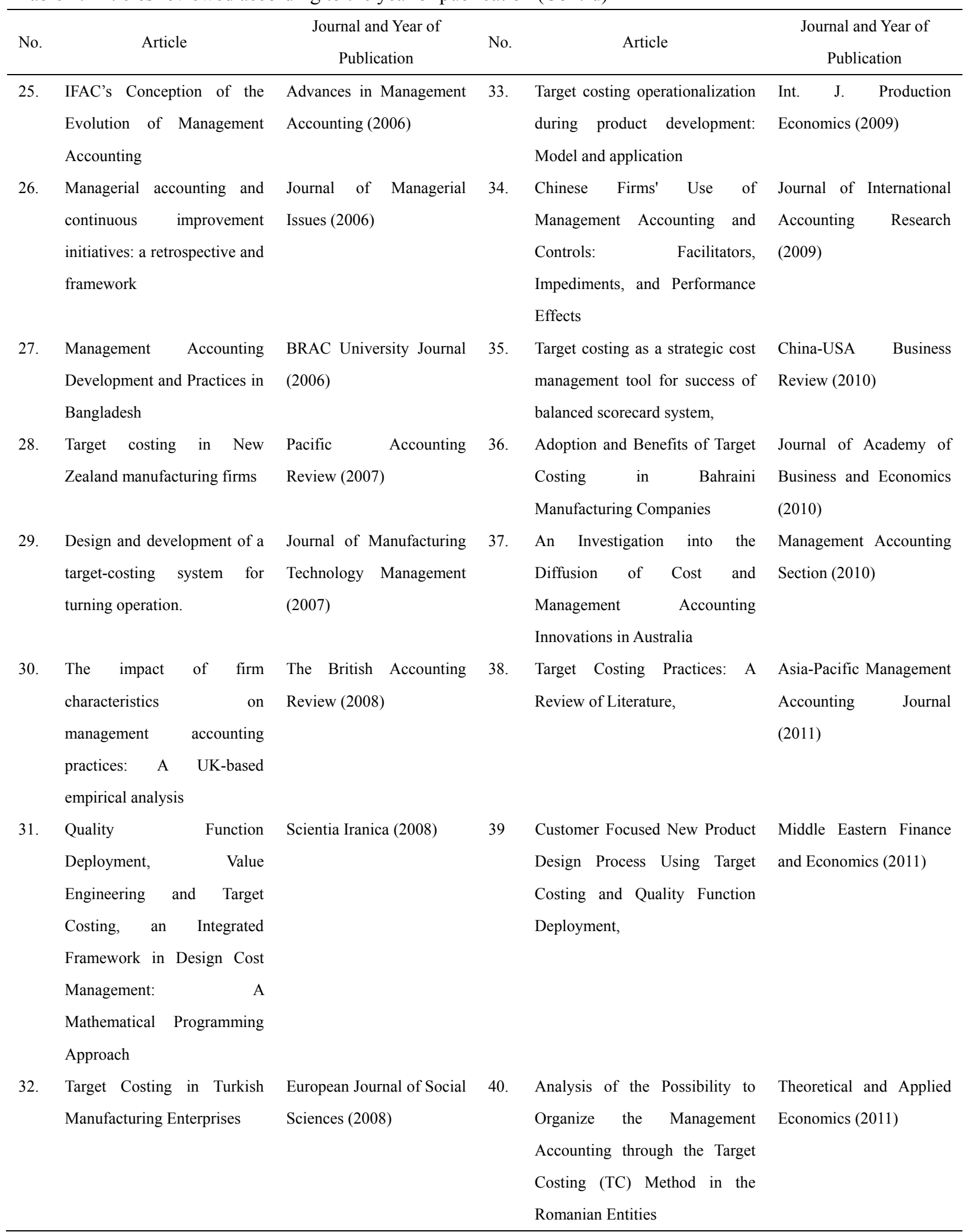

\section{Findings}

\subsection{Evolutionary Diagram of Cost Control System}

To illustrate the development of cost control system as TC is mostly supposed to be a major tool in this system as 
reviewed in the literature, Figure 3 shows the evolutionary diagram of cost control system and certain activities involved in cost control process based on the IFAC's (1998) framework. Through the management accounting evolution framework derived from IFAC (1998), the changes in certain activities and tools involved in cost control system, such as Standard Costing, Kaizen Costing, VE and TC, reflect the changes in management accounting role in different periods. Specifically, TC is seen to be a shift from the traditional control system focusing on standard costs analyzed after production process toward strategic cost control system focusing on cost control in the earlier stages of production process.

However, through the development stages of cost control system illustrated in the Figure 3, it can be said that the recent management accounting techniques have great advantages coming from its close linkages with profit planning strategy of the company. In essence, the linkage of cost improvement activities with the overall strategic planning processes ensure the achievement of the long-term profit goals without being concerned with meeting the standard costs and analyzing the variances being used in the traditional cost control system. Therefore, Monden and Hamadah (1991) claim that the TC must be closely connected with company profit planning. They report that a company focused only on costs may be biased against high cost/high profit products. This means that the linkage of TC with company strategic profit planning would put in personnel minds that the ultimate goal of the company is the highest profit, not cost reduction.

Based on Daihatsu experience presented by Monden and Lee (1993), Kaizen Costing was practiced by using the actual production costs of the previous year as the cost base of the current year. However, this is functioning in a similar way as a budgetary control system in the standard costing process. Then, the cost reductions will be determined from this cost base figure, and the ratio of cost reduction amount to the cost base is called the cost reduction rate (CRR). The CRR is established for each element of the cost base at each year-end for the following year. Hence, the total Kaizen costs would reflect the integrated target reduction rates of all cost base elements. However, certain changes might happen in the mid-year due to the design change of model and alteration of mixed model production. In this case, Value Engineering (VE) comes into practice in the design stage, and TC is also applied in this stage. As VE is the cost reduction activity which involves functional changes in the new product development stage, it differs from Value Analysis (VA) technique where the last focuses only on the cost reduction activities involved in the design stages of the existing products (Monden \& Hamadah, 1991). This supports the active integration between Kaizen Costing and TC to attain the total cost management goal for the company. On account of the above experience of Daihatsu Company, the Total Cost Management (TCM) role is being severe in product design and development stage, as well as production stage. This contrasts with traditional cost management role limited in the production stage for cost control purpose. 


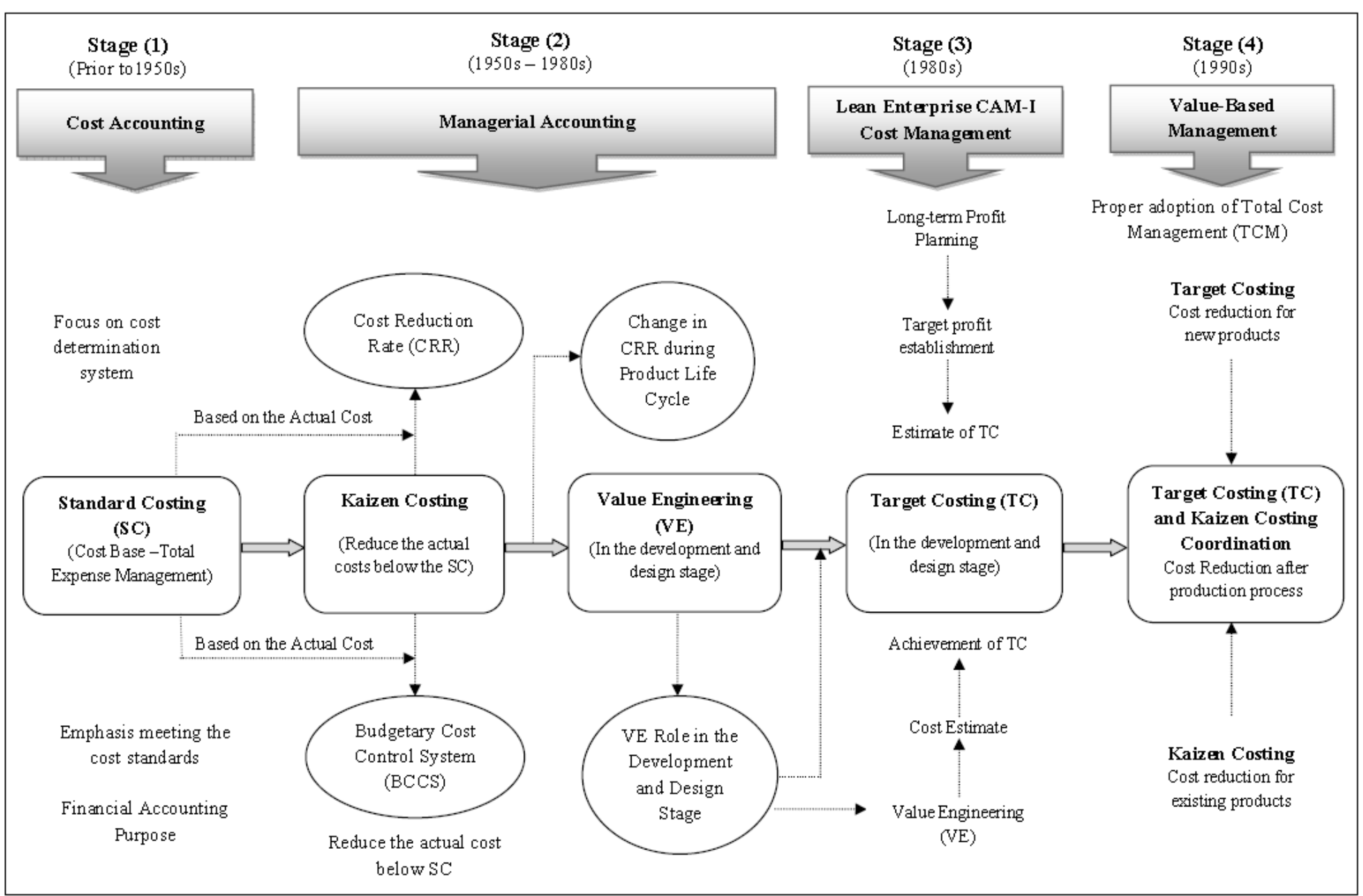

Figure 3. The evolution of cost control system

\subsection{Target Costing Evolution Framework}

TC is commonly known as a cost reduction and control system used to manage product costs during the earlier stages of product life cycles. It basically starts with identifying the selling price that the customers are willing to pay with specific quality and functionality. Hence, it differs from traditional costing method, such as cost-plus in determining selling price, and standard costing in timely product costs controlling. However, TC has been evolved from cost reduction and control to cost management and quality and functionality improvement over times. The need for TC evolution framework is a part from the need of management accounting evolution framework discussed earlier. Within the management accounting evolution framework derived from IFAC (1998) (see Figure 1), the development of TC can be described and guided as an effective tool of management accounting practices. As for the Japanese experience in developing TC, there are many factors which helped Japanese companies to develop and implement TC successfully (Feil, Yook, \& Kim, 2004). These include top management leadership, team-orientation, team-commitment, mutual trust built between managers and employees, management accounting structure, employees' education, and information network with customers and suppliers. Based on these factors, the conceptual framework of TC is developed as shown in Figure 4 which is consistent with the conceptual framework of management accounting evolution. 


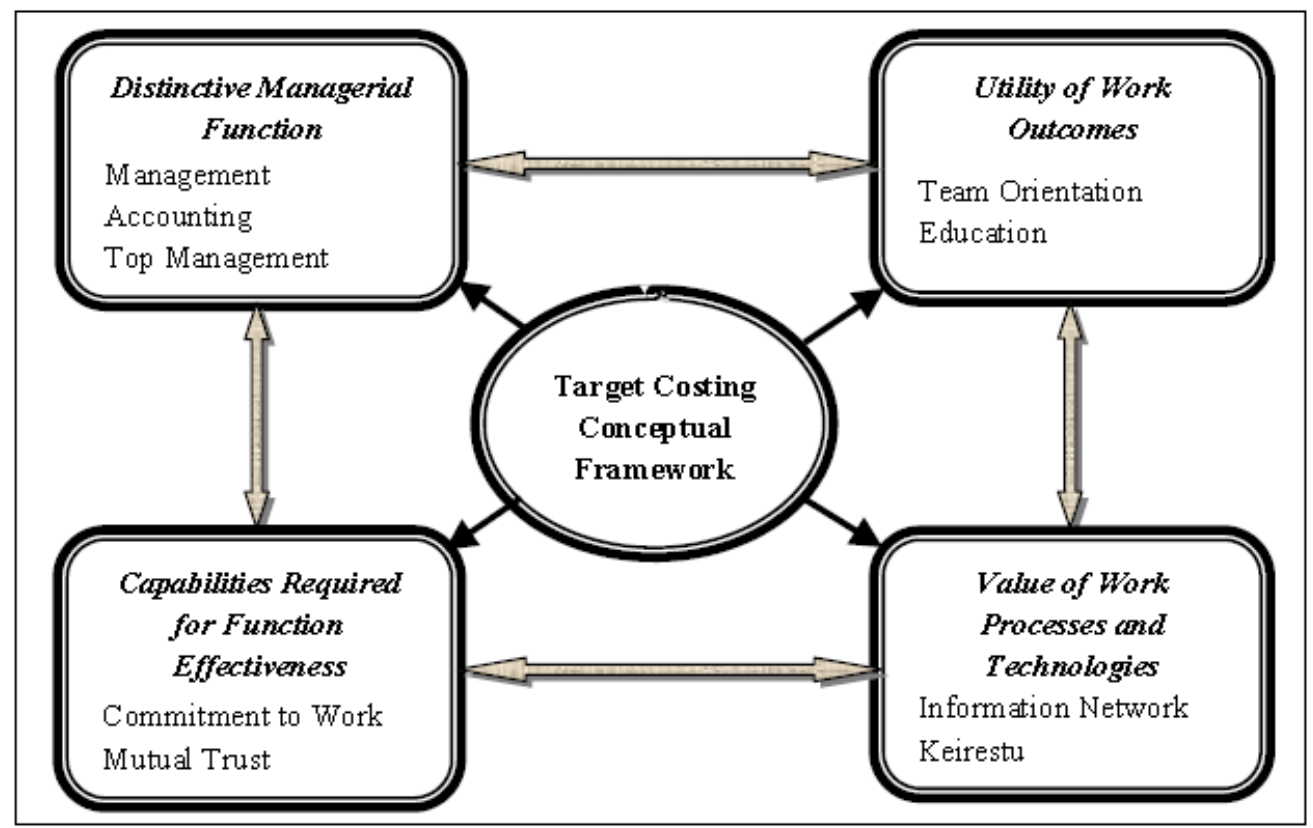

Figure 4. The conceptual framework of target costing

Based on the Elements of Japanese Target Costing Cited from Feil et al. (2004)

In the context of the conceptual framework illustrated above, the framework requires integrating the TC technique with other strategic cost management techniques. According to Kato (1993), TC is a combination of many techniques reinforced by the TC practice. Hence, the TC focus on cost reduction objective can be achieved through the effective use of organizational resources integrated with other managerial functions. In addition, in the "TC Operationalization Model" developed by Filomena et al. (2009), TC practice is separated into four different stages namely; (1) define product parts, features and common elements, (2) present the unitary target product development costs, (3) product TC calculation, and (4) define the insertion of TC breakdown into parts and features. They reported that the proposed model enables Brazilian companies to integrate TC with other cost control tools, and then functional teams to have accurate cost control. However, integrating TC with other cost control techniques is to ensure opportunities for value creation driven by continuous improvement initiatives in management accounting. Therefore, in the proposed framework, the integration of all cost and management accounting techniques is the predominant factor for achieving the desire of a success implementation of TC.

\subsection{Target Costing Evolutionary Diagram}

The concept of TC has been used for almost several decades. Since its establishment in the 1960s by Japanese firms, TC has been promoted and successfully implemented in non-Japanese firms. However, TC is mainly initiated to support New Product Development (NPD) among manufacturing industries in terms of cost reduction without sacrificing the features of quality and functionality demanded by customers. The evolutionary diagram proposed in this study shows how the TC technique has served these objectives over times. In addition, this function has been evolved to include existing products in terms of product quality and functionality improvement and not only cost reduction. This means that the TC role is shifted towards products marketable value as the management accounting has been evolved toward value creation. Figure 5 shows the evolutionary diagram of the TC based on the literature reviewed and in consistent with IFAC's (1998) framework of management accounting evolution. 


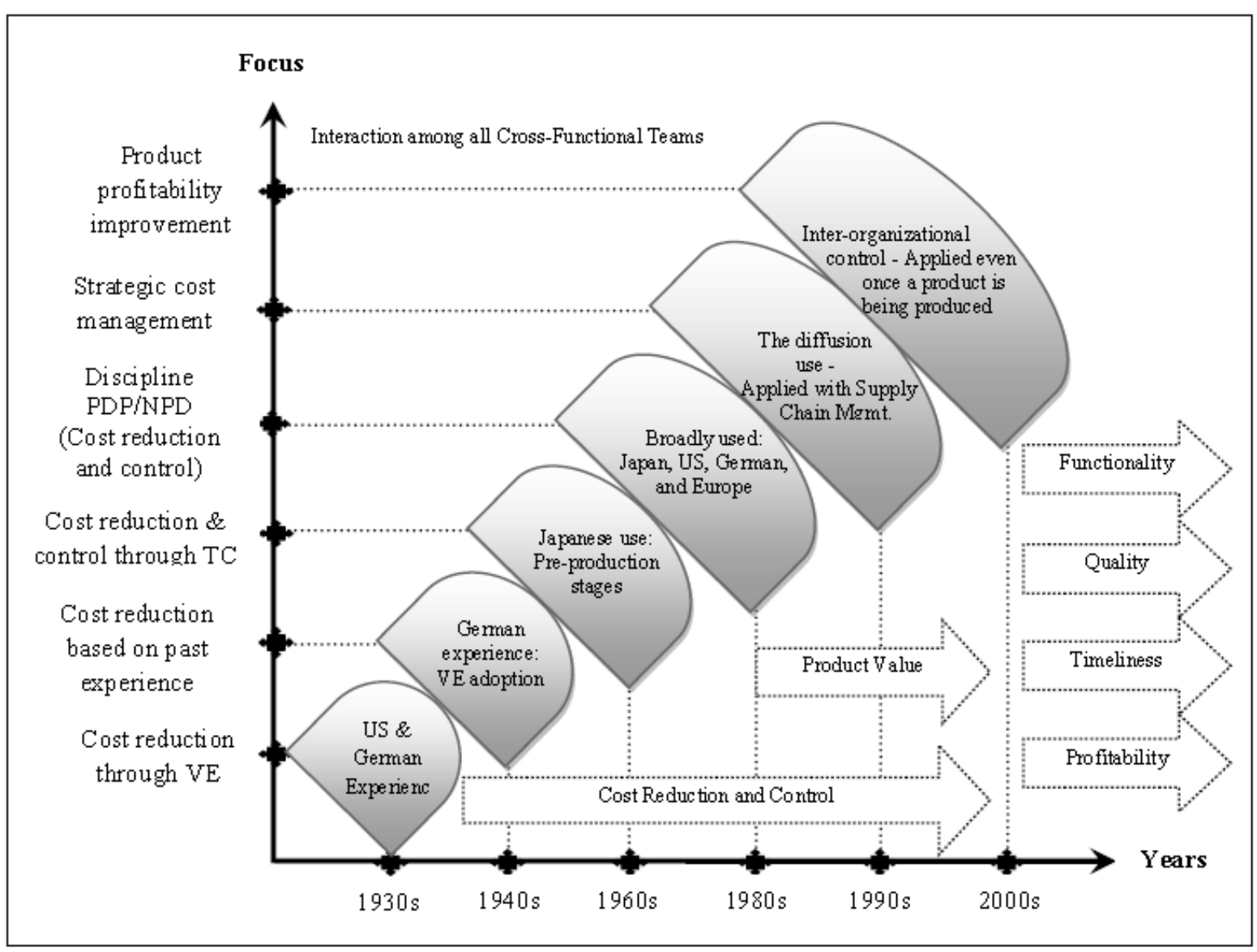

Figure 5. Evolution diagram of target costing

\subsubsection{Introduction of Target Costing Before 1950s}

Based on IFAC's (1998) evolution framework of management accounting, the role of management accounting before 1950s was predominantly oriented toward cost determination of product. According to Johnson and Kaplan (1987), most of cost and accounting techniques were developed during the nineteenth century, in particular at the first quarter of the nineteenth century. Their argument supports the endeavor of most organizations to adopt accurate cost accounting techniques to trace costs in production lines before the First World War. As Johnson and Kaplan reported, before the World War 1 many organizations were using almost all of the cost and management accounting procedures for planning and controlling purposes, and these procedures were still known until the 1980s. Additionally, Askarany (2010) mentioned that the use of Standard Costing and Variance Analysis technique of actual costs and standard costs for the purpose of controlling operations were developed during the nineteenth century. Furthermore, Activity-Based-Costing and Standard Costing were the old techniques of accurate cost accounting system (Askarany, 2005). However, as the major feature of TC concept is the determining of products' target cost, this can be found early in the beginning of the nineteenth century at Ford in the US and in the development of the Volkswagen Beetle in Germany in the 1930s (Feil et al., 2004). This implies that the origin and first application of TC were by the US and German companies in the 1930s but not under the name of "Target Costing" where the typical application of the TC concept was by Japanese Toyota in the 1960s. The concept was later known as the Toyota Production System (TPS).

However, the production process during this time was simple with different manufacturing processes. Besides that, the product costs, including material, labor, and overhead usually assigned based on direct labor, were simply identified and controlled manually. Interestingly, using simple cost and management accounting procedures among the US companies were rarely used to identify products cost and overall evaluate the internal manufacturing processes (Ansari, Bell, \& the CAM-I Target Cost Care Group, 1997; Feil et al., 2004). In addition, the intention to develop standards to monitor material, labor, and overhead costs was noticed among American companies through using Standard Costing (Ansari et al., 1997). Historically, Standard Costing has 
been adopted by many organizations for the aim of financial accounting reporting and financial performance evaluation. Moreover, the main focus during the time of Standard Costing use was to control products cost in meeting standards through the analysis of variance between actual and standard costs for controlling manufacturing processes, but not for cost reduction purpose. However, during the 1930s, Americans created a concept of maximizing the product attributes with minimizing product cost (Leahy, 1996; as cited by Feil et al., 2004). This technique became known as "Value Engineering" (VE) and was subsequently adopted by Japanese companies to resist the competitive environment in Japan. Moreover, the VE use was a substantial incentive and innovation for Japanese management accounting system towards TC implementation.

\subsubsection{Target Costing between 1960s and 1980s}

TC has a history of more than 40 years in the Japanese companies (Gopalakrishnan, Kokatnur \& Gupta, 2007). It seems to be more relevant to studies conducted in Japanese companies, where it explicitly appeared as a cost management technique adopted by Japanese management accountants (Kato, 1993; Tani et al., 1994; Tani, 1995). Although many industries in Japan use TC, the system was preliminarily developed by Toyota Motor Corporation in 1959, and is considered the oldest and the most technically advanced (Gopalakrishnan et al., 2007). However, the focus on providing accurate accounting information for the purpose of planning and control decision making is the fundamental role of management accounting seen by IFAC (1998) in 1965. In addition, the strategic and environmental considerations and management controls were predominantly oriented towards manufacturing processes and internal administration in the 1960s. Hence, TC technique adopted by Japanese manufacturers was one of the cost and management accounting techniques introduced by many organizations since the 1960s around the world for meeting this objective.

However, the first use of VE occurred at 1963 by Toyota, and this practice was known as "Genka Kikako" (Tani et al., 1996; as cited by Feil et al., 2004). This practice was translated into "Target Costing" (Kato, 1993), but it was not mentioned in Japanese literature until 1978 (Tani et al., 1996; as cited by Feil et al., 2004). In addition, during the 1980s, TC implementation, as a key cost accounting approach, has been rapid and its popularity has increased greatly, especially in Japan where it has become a major element in the strategic cost management of Japanese companies (Tanaka et al., 2006, p. 35; Feil et al., 2004). Meanwhile, Japanese companies' implementation of TC is followed by many companies in the US and Europe as a response to increasing pressure of supply chains coupled with new pressure of capital market during this period in these countries (Juhmani, 2010). Therefore, the active role of supply chain involvement in the US and European TC practices is higher than in Japanese TC practice. According to Hamood et al. (2011), the success of TC adoption depends on credible information gathered from marketplace. They conclude that supply chain management plays a major role to link TC goals with customers' desires and market demands through the interactive involvement of suppliers in TC practices.

\subsubsection{Target Costing between 1980s and 1990s}

In meeting the challenges of increased competition worldwide, introducing new management and production techniques, especially for controlling costs through waste reduction in resources used in production processes, is being necessary (IFAC, 1998). Kader and Luther (2004) reported that the increased global competition in the early 1980s following the shock of oil price and accompanied by rapid technological development have affected many aspects of industrial sector. Hence, the adoption of cost management techniques by which accurate information would be available has been diffused throughout the organizations. According to Smith (1999), as cited by Sharkar, Sobhan and Sultana (2006), the most popular cost and management accounting innovations developed in the 1980s include: Activity-Based-Costing, Target Costing, Value-Added Management, Theory of Constrain, Vertical Integration, Private Labels, and Benchmarking. However, in the late 1980s, TC was used broadly in the US, Germany and other European companies, but it came into Turkish literature in the mid 1990s (Kocsoy, Gurdal \& Karabayir, 2008). Moreover, Ansari et al. (1997) report that American and European companies started to adopt TC since the late 1980s. Cooper and Slamulder (1999), in their description of the "generic approach" to Japanese TC, argue that Western companies are introducing TC in order to discipline their Product Development Process (PDP). On the other hand, many large companies in North America and Europe have attempted to adopt TC to enhance their cost management and, thus, increase their competitiveness (Feil et al., 2004). Hence, TC during this period is commonly known as a cost management used to drastically manage product costs rather than reduce and control product costs. During this period also, it can be noticed that the diffusion involvement of supply chain management in TC practices as a main source of needed information to insure product value. 


\subsubsection{Target Costing between 1990s and 2000s}

During this period, many Eastern companies have attempted to adopt TC to promote their product globally, such as Australia (Chenhall \& Langfield-Smith, 1998), India (Joshi, 2001), China (Duh, Xiao, \& Chow, 2009) and Turkey (Kocsoy et al., 2008). Due to rapid changes in customer expectations and product varieties in this period, most of manufacturers worldwide are continuously seeking to produce lower cost products designed with functionality and quality. However, based on IFAC's (1998) statement, the focus of management accountants was shifted towards value generation through an effective use of business resources to ensure the drivers of customer value, shareholders value, and organizational innovation. Hence, TC has become a necessity in making a trade-off between all these factors. This is to ensure profitability and sustainability to survive in a severe competitive environment. As a consequence, TC, as it is a cost management technique in the last decades, is seen as a tool of profit management especially after the 1990s where most industries faced uncertainty challenges in information processing and e-commerce appearance. Dekker and Smidt (2003) reveal a significant positive relationship between TC implementation and the intensity of competition. Meanwhile, Kocsoy et al. (2008) claim that the increased competition combined with a dynamic environment encourage the TC application by Turkish manufacturing companies. On the other hand, Rattray, Lord and Shanahan (2007) find that the TC was perceived among New Zealand firms as being the most important tool for cost reduction followed by customer satisfaction, quality and the timeliness for new products.

\subsubsection{Target Costing after 2000s}

Over the 2000s, cost and management accounting techniques have been developed to shift its functions towards professional responsibility. This notifies that the development of management accounting seen in IFAC's (1998) statement is actually recognized to be a wide scope of skills and expertise integrating certain techniques in meeting value creation without focus only on financial objectives. In addition, the integrated adoption of various techniques is the main feature of the period over the 2000s in order to provide complementary benefits other than those of the individual techniques. In essence, Shank and Govindarajan (1989), as cited by Adler et al. (2000), argue for the need to integrate cost accounting with strategic management. In addition, Nishimure (2002) suggests that the integration of accounting management and organization management is indispensable for the feed forward rather than feedback control system, and for the market orientation rather than production. This is supported by the evidence found in a case study of Romanian manufacturing company studied by Sorinel and Sorin (2011). They found that the management accountants are the main observer of the impact of competitive market and the increase or decrease of price and costs in the TC practice, and then pass all these signals to the organization management. Hence, TC technique has emerged as a market-oriented system which effectively manages the new product costs in the design and development stage (Monden \& Lee, 1993). They report that the TC employed together with Kaizen Costing helps Japanese automobile industries to achieve their goal of cost reduction in the entire product design and development stage. Additionally, Monden (1995) explains Toyota's cost reduction process starting from TC's role in the product design and development stage and carrying through Kaizen Costing in the production stage. Therefore, Japanese companies have learned to adopt TC not as a stand-alone technique, but in fact, they view TC as an integral part of the product design and development processes. On other hand, Cokins (2002) reveals in his study on US companies the perceived benefits of integrating TC with $\mathrm{ABC}$ especially in the target costs allocation process. Souissi \& Ito (2004) also suggest that integrating TC and BSC through adopting the four perspectives of BSC to support the frequent processes occurred to decomposing the gap between TC and estimated cost would help to get the right balance among all the three crucial elements of TC: cost, quality and functionality. Similarly, Yilmaz and Baral (2010) comment that the TC has some similarities in certain aspects with BSC as both are used specifically to satisfy customers' needs and requirements for achieving financial objectives and overall strategic objectives. On the other hand, as seen in Figure 5, the focus of TC adoption in not seen from financial perspective "cost reduction" but also from non-financial perspective "quality and functionality and lead time". In this regard, Barrows and Chanhall (2012) affirm that the presence of TC after 2000s is as a product-development system rather than a product-costing technique prior to 2000s. Meanwhile, Pakizeh et al. (2013) found TC as an integral powerful strategic system containing various economic tools. The system has enabled Iranian companies to handle three dimensions: cost, quality and time, as well as control the product cost beforehand and ultimately increase the profitability. In general, the recent attention of many organizations worldwide is to find out the ways in which TC can be implemented successfully to enhance organizational performance toward product value creation and profitability growth, not only for new products but also for existing products.

\section{Discussion}

Through the stages of TC evolution stated above, the last two decades have spurred the development of cost 
management and cost control innovations, and there have been significant changes in its role for meeting the global competition challenges. Certain activities and tools have been used in cost control system such as Standard Costing, Kaizen Costing, VE and TC. These tools have recently become as complementary tools for the TC implementation. However, as TC is one of the cost control and management accounting innovations, the intention toward its adoption between the 1960s and 1980s is exclusive in Japan, US, Germany, and some European countries. In supporting this view, many US companies have adopted Standard Costing system to control product cost during the production processes before the 1960s. This was exclusively for meeting standards costs and achieving financial objectives. In addition, there is a numinous view among researchers in the literature in regard to the insufficiency of Standard Costing system, as a traditional technique, in terms of cost reduction. As a result, Kaizen Costing system has increasingly been implemented to support continuous improvement in cost reduction process. This was an inception of TC adoption especially in Japan within the two earlier decades (1960s and 1980s) which was accordingly translated into Western companies with some specific characteristics.

On the other hand, TC implementation was diffused to involve some developing countries between the 1980s and 1990s. In supporting this view, Kaplan (1994) asserts that the period of 1980s to 1990s have noticed a significant revolution in cost and management accounting theory and procedures. Empirically, it was noticed from the literature review that increased attention had been paid by many organizations worldwide towards this technique not only as a cost reduction tool, but also as a cost management tool, aiming to improve product quality, functionality and timeliness. This is the key feature of TC implementation so as to enable organizations to improve profitability and ultimately to compete among its competitors. Recently, especially after 2000 the intention of most organizations is concerned with the integration of management accounting techniques. This is obviously noticed in the Japanese experience of TC adoption integrated with Kaizen Costing system, and US integration of TC with $\mathrm{ABC}$. Hence, as TC is being widely recognized as a cost and profit management tool, it is supposed to be an integral system incorporating certain management accounting techniques utilized by many organizations in facing today's multitude of challenges in business environment.

However, it is noticed that most of the TC studies reviewed are dominated in the journal of Management Accounting Research as this journal mainly contributes to improve management accounting practices where TC is one of them. To support TC evolution discussed in this study, some of the studies pertaining to TC practice have been published in other global scientific journals and European countries, in particular, such as European Journal of Social Sciences and Corporate Relation Journal. Further, it has been evolved and studied in certain Eastern countries, as an attempt to recognize TC role among other newly management accounting techniques, such as Middle Eastern Finance and Economics Journal and Asia pacific Management Accounting Journal. Especially, in Malaysia where much focus of many researchers and practitioners is given to recent management accounting techniques such as TC.

\section{Conclusion}

Based on the literature review, TC is mainly initiated by Japanese companies in the 1960s as a cost reduction and control system used to manage product costs during the earlier stages of product life cycles. The evidence reviewed suggests that the TC has been promoted in non-Japanese companies to ensure its product competitiveness in terms of cost, quality and functionality. Based on IFAC's (1998) framework of management accounting evolution, the main objective of this study is to examine the evolution of TC in consistence with the management accounting evolution in different periods. This study attempts to show how the TC has been diffused to non-Japanese companies worldwide and evolved from cost reduction and control to cost management, quality and functionality improvement. As TC is supposed to be a major tool of cost control system, the evolutionary diagram of cost control system is developed and discussed to show how the TC has served the objective of cost control over times. However, the development of cost reduction and control tools through the TC evolutionary diagram developed in this study indicates the TC evolution in consistence with the management accounting evolution described by IFAC (1998). Moreover, the role of TC is developed in coping with severe global competition and rapid technological development in manufacturing and information processing techniques. This contrasts with Johnson and Kaplan's (1987) argument that the management accounting had not changed and lost its relevance in providing information for decision making since the early of the twentieth century.

The main limitation of this study is the ignorance of factors influencing TC development including both environmental and organizational factors. Specifically, TC has been evolved and adopted by many organizations operating in other business environment than its original inception in Japanese environment. Hence, it is very interesting to explore the organizational changes happened and capabilities required for adopting this technique 
in non-Japanese context. Moreover, OCs, such as organizational structure, strategy, culture, size, and relations, have been addressed in the literature as success factors for TC evolution, and constitute the fundamental elements for companies to determine its readiness to develop TC technique (Hamood, et al., 2011). Therefore, future research on TC development decisions and OCs is highly encouraged to investigate the effect of these factors on the success of TC development. It is hoped through conducting future research to circumvent this limitation and find out in a comparative way the factors behind the lower adoption rate of TC among some developing countries than those found in Japan, the US and European countries.

\section{References}

Abdel-Kader, M., \& Luther, R. (2006). IFAC's Conception of the Evolution of Management Accounting. Advances in Management Accounting, 15, 229-247. http://dx.doi.org/10.1016/S1474-7871(06)15010-8

Abdel-Kader, M., \& Luther, R. (2008). The impact of firm characteristics on management accounting practices: A UK-based empirical analysis. The British Accounting Review, 40, 2-27. http://dx.doi.org/10.1016/j.bar.2007.11.003

Adler, R., Everett, A. M., \& Waldron, M. (2000). Advanced Management Accounting Techniques in Manufacturing: Utilization, Benefits, and Barriers to Implementation. Accounting Forum, 24(2), 131. http://dx.doi.org/10.1111/1467-6303.00032

Albright, T., \& Lam, M. (2006). Managerial accounting and continuous improvement initiatives: A retrospective and framework. Journal of Managerial Issues, 18(2), 157-175.

Ansari, S. L., Bell, J. E., \& the CAM-I Target Cost Care Group. (1997). Target Costing: The Next Frontier in Strategic Cost Management. Chicago, Iwrin Professional Publishing.

Askarany, D. (2005). The evolution of management accounting innovations and the level of satisfaction with traditional accounting techniques. 2005 AFAANZ Conference, Melbourne, Australia, July.

Askarany, D. (2010). An Investigation into the Diffusion of Cost and Management Accounting Innovations in Australia. AAA 2010, Management Accounting Section (MAS) Meeting, Australia.

Bright, J., Davies, R. E., Downes, C. A., \& Sweeting, R. C. (1992). The development of costing techniques and practices: A UK study. Management Accounting Research, 3, 201-211. http://dx.doi.org/10.1016/S1044-5005(92)70011-0

Burrows, G., \& Chenhall, R. H. (2012), Target costing: First and second comings. Accounting History Review, 22(2), 127-142. http://dx.doi.org/10.1080/21552851.2012.681124

Chenhall, R., \& Langfield-Smith, K. (1998). Adoption and benefits of management accounting practices: An Australian study. Management Accounting Research, (9), 1-19. http://dx.doi.org/10.1006/mare.1997.0060

Cokins, G. (2002). Integrations of Target Costing and ABC. Journal of Cost Management, 6(4), 13-22.

Cooper, R., \& Slagmulder, R. (1997). Target Costing and Value Engineering. Portland, Oregon, Productivity Press.

Dekker, H., \& Smidt, P. (2003). A survey of the adoption and use of target costing in Dutch firms. Int. J. Production Economics, 84, 293-305. http://dx.doi.org/10.1016/S0925-5273(02)00450-4

Duh, R.-R., Xiao, J. Z., \& Chow, C. W. (2009). Chinese Firms' Use of Management Accounting and Controls: Facilitators, Impediments, and Performance Effects. Journal of International Accounting Research, 8(1), 1. http://dx.doi.org/10.2308/jiar.2009.8.1.1

Feil, P., Yook, K.-H., \& Kim, I.-W. (2004). Japanese Target Costing: A Historical Perspective. International Journal of Strategic Cost Management, (Spring), 10-19.

Filomena, T. P., Jose, F., Neto, K., \& Duffey, M. R. (2009). Target costing operationalization during product development: Model and application. Int. J. Production Economics, 118, 398-409. http://dx.doi.org/10.1016/j.ijpe.2008.12.007

Gopalakrishnan, B., Kokatnur, A., \& Gupta, D. P. (2007). Design and development of a target-costing system for turning operation. Journal of Manufacturing Technology Management, 18(2), 217-238. http://dx.doi.org/10.1108/17410380710722917

Hagerty, M. R. (1997). A Powerful Tool for Diagnosis and Strategy. Journal of Management Consulting, 9(4), $16-25$.

Hamood, H. H., Omar, N., \& Sulaiman, S. (2011). Target Costing Practices: A Review of Literature. Asia-Pacific 
Management Accounting Journal, 6(1), 1-24.

Helms, M. M., Ettkin, L. P., Baxter, J. T., \& Gordon, M. W. (2005). Managerial Implications of Target Costing. $C R, 15(1), 49-56$.

Hiromoto, T. (1991). Restoring the Relevance of Management Accounting. Journal of Management Accounting Research, 3(Fall).

International Federation of Accountants (IFAC). (1998). International Management Accounting Practice Statement: Management Accounting Concepts. Financial and Management Accounting Committee, March 1998, New York, 82-100.

Jariri, F., \& Zegordi, S. H. (2008). Quality Function Deployment, Value Engineering and Target Costing, an Integrated Framework in Design Cost Management: A Mathematical Programming Approach. Scientia Iranica, 15(3), 405-411.

Johnson, H. T., \& Kaplan, R. S. (1987). Relevance Lost- The Rise and Fall of Management Accounting. Harvard Business School Press, Boston, Massachusetts.

Joshi, P. (2001). The international diffusion of new management accounting practices: The case of India. Journal of International Accounting, Auditing and Taxation, (10), 85-109. http://dx.doi.org/10.1016/S1061-9518(01)00037-4

Juhmani, O. I. H. (2010). Adoption and Benefits of Target Costing in Bahraini Manufacturing Companies. Journal of Academy of Business and Economics, 10(1), 113-122.

Kader, M. A., \& Luther R. (2004). An Empirical Investigation of the Evolution of Management Accounting Practices. University of Essex, Working Paper Series, 04/06, October.

Kaplan, R. S. (1984, July). The evolution of management accounting. The Accounting Review, 390-418.

Kaplan, R. S. (1994). Management accounting (1984-1994): Development of new practice and theory. Management Accounting Research, 5, 247-260. http://dx.doi.org/10.1006/mare.1994.1015

Kato, Y. (1993). Target costing support systems: Lessons from leading Japanese companies. Management Accounting Research, 4, 33-47. http://dx.doi.org/10.1006/mare.1993.1002

Kocsoy, M., Gurdal, K., \& Karabayir, M. E. (2008). Target Costing in Turkish Manufacturing Enterprises. European Journal of Social Sciences, 7(2), 92-105.

Modarress, B., Ansari, A., \& Lockwood, D. L. (2005). Kaizen costing for lean manufacturing: A case study. International Journal of Production Research, 43(9), http://dx.doi.org/10.1080/00207540500034174

Monden, Y. (1995). Cost Reduction Systems: Target Costing and Kaizen Costing. Portland, Oregon, Productivity Press.

Monden, Y., \& Hamada, K. (1991). Target costing and kaizen costing in Japanese automobile companies. Journal of Management Accounting Research, 3, 16-34.

Monden, Y., \& Lee, J. (1993). How a Japanese auto maker reduces costs. Management Accounting, 72(2), ABI/INFORM Global, 22.

Nishimura A. (2002). Asia Economic Growth and Management Accounting. Malaysian Accounting Review, 1(1), 87-101.

Pakizeh, F., Vali, S., Hanzaei, T., \& Moradi, M. (2013). Feasibility Assessment of Target Costing in Yasuj Cement Factory. International Journal of Advanced Studies in Humanities and Social Science, 1(4), 290-297.

Rattray, C. J., Lord, B. R., \& Shanahan, Y. P. (2007). Target costing in New Zealand manufacturing firms. Pacific Accounting Review, 19(1), 68-83. http://dx.doi.org/10.1108/01140580710754656

Sharkar, M. Z. H., Sobhan, M. A., \& Sultana, S. (2006). Management Accounting Development and Practices in Bangladesh. BRAC University Journal, III(2), 113-124.

Smith, M. (1999). Management Accounting for Competitive Advantage (1st ed.). Sydney: LBC Information Services.

Sorinel, C., \& Sorin, B. (2011). Analysis of the Possibility to Organize the Management Accounting through the Target Costing (TC) Method in the Romanian Entities. Theoretical and Applied Economics, XVIII(562), 
71-88.

Souissi, M., \& Ito, K. (2004). Integrating target costing and the balanced scorecard. The Journal of Corporate Accounting \& Finance, 15(6), 57. http://dx.doi.org/10.1002/jcaf.20057

Tani, T. (1995). Interactive control in target cost management. Management Accounting Research, 6, 399-414. http://dx.doi.org/10.1006/mare.1995.1028

Tani, T., Okano, H., Shimizu, N., Iwabuchi, Y., Fukuda, J., \& Cooray, S. (1994). Target cost management in Japanese companies: current state of the art. Management Accounting Research, 5, 67-81. http://dx.doi.org/10.1006/mare.1994.1005

Yalcin, S. (2011). Customer Focused New Product Design Process Using Target Costing and Quality Function Deployment. Middle Eastern Finance and Economics, 11, 118-131.

Yilmaz, R., \& Baral, G. (2010). Target costing as a strategic cost management tool for success of balanced scorecard system. China-USA Business Review, 9(3), 39-53.

\section{Copyrights}

Copyright for this article is retained by the author(s), with first publication rights granted to the journal.

This is an open-access article distributed under the terms and conditions of the Creative Commons Attribution license (http://creativecommons.org/licenses/by/3.0/). 